Rami Mähkä

\section{MONTY PYTHONIN KOMEDIA VASTAELOKUVANA}

\author{
Englantilainen elokuvateoreetikko Peter Wollen (s. 1938) lanseerasi vuonna \\ 1972 termin "vastaelokuva" kuvaamaan Jean-Luc Godardin elokuvaa suhteessa \\ valtavirran elokuvaan. Vastaelokuva muistuttaa jatkuvasti katsojaa siitä, että \\ tämä katsoo elokuvaa konstruoituna tekstinä, ei "todellisuutena". Artikkelissa \\ Wollenin typologiaa sovelletaan Monty Pythonin komediaan, jossa on vah- \\ vat vastaelokuvalliset piirteensä. Huomionarvoisaa on, että Monty Pythonin \\ median roolia korostava komedia ja vastaelokuvakeskustelu olivat samanaikaisia \\ ilmiöitü. Ne ilmentävät 1960-1970-lukujen elokuvaesteettistä ja -kerronnallista \\ ajattelua.
}

Brittiläis-amerikkalaisen komediaryhmä Monty Pythonin toinen elokuva Hullu maailma (Monty Python and the Holy Grail, Terry Jones ja Terry Gilliam, Iso-Britannia 1975) alkaa kohtauksella, jossa ainoa sumuisessa maisemassa näkyvä objekti on pahaenteinen teilipyörä. Tuulenujelluksen lisäksi alkaa kuulua muutakin, hevosten laukkaamista ja metallin hankausta metallia vasten. Jo ennakkomainonnasta katsoja on saanut tietää, että elokuva, jonka katsomisen hän on juuri aloittanut, on komedia kuningas Arthurista ja Graalin maljan etsinnästä. Vaikka elokuvan alkutekstit ovat hölynpölyä ja sisältävät katsojan suoraa puhuttelua, tämä ei voi tietää, miten alkutestien ekstradiegeettinen hauskuuttaminen liittyy elokuvan diegeettisen maailman komediallisuuteen. ${ }^{1}$

Elokuvan aihe ja ääniraidalta kuuluvat äänet johtavat katsojan odottamaan, että millä hetkellä hyvänsä sumusta ratsastaa esiin haarniskaan pukeutuneita, miekoilla ja muilla keskiaikaisilla aseilla varustautuneita ratsumiehiä, ritareita. Tavallaan näin tapahtuukin, mutta ritareilla ei ole hevosia, vaan he "laukkaavat" itse. Ääniefektin lähde jää tässä vaiheessa epäselväksi, ${ }^{2}$ mutta selvää on, että katsojan ennakko-odotukset ovat mitä suurimmalla todennäköisyydellä osoittautuneet vääriksi. Tämän artikkelin teeman kannalta vielä oleellisempaa on, että valtavirran elokuvalle ominainen pyrkimys mimeettiseen eheyteen rikotaan heti elokuvan alkusekunneilla, jolloin katsojan tempautuminen mukaan tarinamaailmaan jää toteutumatta. Pikemminkin hän jää odottamaan seuraavaa vitsiä tai gagia, joita elokuvassa todella riittää.

Tämä artikkeli tarkastelee Monty Pythonin 1970-luvun televisio- ja elokuvakomediaa Peter Wollenin vastaelokuvan käsitteen avulla. Tarkoituksena on ymmärtää sitä elokuvakulttuuria, joka loi vastaelokuvan kulttuurisena ilmiönä ja jonka Monty Python omaksui oman komediansa tärkeäksi elementiksi, ei
Rami Mähkä, FT

Kulttuurihistoria, Turun yliopisto

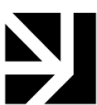

VERTAISARVIOITU KOLLEGIALT GRANSKAD PEER-REVIEWED Www.tsv.fi/tunnus

1 Gérard Genette (1997) kirjoittaa parateksteistä eli tekstiin liittyvistä ja kuuluvista keinoista ja konventioista, jotka toimivat kirjan, kirjoittajan ja lukijan/vastaanottajan välisenä viestintänä. Analysoimassani Hullun maailman tapauksessa tällaisia ovat juuri tekstissä mainitut ennakkomainonta (ulkoinen) ja elokuvan alkutekstit (sisäinen).

2 Selviää, että "ratsastajat" tuottavat ääniefektin kookospähkinän kuorilla. Seuraa pitkä keskustelu siitä, miten kookospähkinänkuoret ovat Englantiin päätyneet sekä siitä, miten eri mantereiden pääskyt pystyvät kantamaan taakkoja. Aiheet rikkovat keskiaikaelokuvan konventioita ollen näin omalla tavallaan vastaelokuvallista komediaa. 
siis esimerkiksi todistaa Wollenin käsitettä oikeaksi tai vääräksi. ${ }^{3}$ Wollenin vuonna 1972 lanseeraaman käsitteen idea on, että erityisesti Jean-Luc Godardin elokuva oli "vastaelokuvaa" (counter-cinema) etupäässä Hollywoodin edustamalle, hallitsevalle (dominant) valtavirranelokuvalle ja erityisesti sen kerronnalle. Vastaelokuvalle on Wollenin mukaan keskeistä, että se muistuttaa katsojaa siitä, että tämä katsoo elokuvaa ja suhtautuu näin tietoisesti valkokankaalla esitettyihin tapahtumiin. Vaikka David Bordwellin (1979, 716-724) mukaan taide-elokuva ylipäätään määrittyy klassista Hollywood-kerrontaa vasten, on selvää, että vastaelokuva Wollenin määrittämässä mielessä ei ole taide-elokuvankaan valtavirtaa. ${ }^{4}$

Godardin elokuvat eivät ole komediaa, kun taas Monty Python on. Kuitenkin Monty Pythonin komediassa on merkittävän paljon yhteistä Wollenin teesien kanssa, ja on erittäin huomionarvoisaa, että kyseessä on siis aikalaisilmiöt. On painotettava, että Wollen toimii artikkelissa alkuperäislähteenä (Wollen 1982, 79-91), ei tutkimuksena, vaikka vastaelokuva onkin teoreettinen malli. Lisäksi Monty Python sekä arvosti että parodioi Godardia ja uuden aallon elokuvaa sekä muuta ajan taide-elokuvaa, kuten alla selviää. Väitänkin, että komedialla ja vastaelokuvalla on pitkälti samankaltainen asenne valtavirran ei-komediaelokuvaan, mutta artikkeli tuo esiin myös vastaelokuvan ja komedian erot: toisin sanoen artikkelissa ei-komediasta laadittu teoreettinen malli auttaa ymmärtämään komediaa, mutta ei-komediallinen malli ei voi sisältää kuin osan komedian vastaelokuvallisuudesta.

Artikkeli etenee seuraavasti: Monty Pythonin ja vastaelokuvaan 1970-luvulla liittyneen keskustelun esittelyn jälkeen siirrytään kirjallisuudentutkija Maurice Charneyn komedian erityispiirteiden erittelyyn (Charney 1987 [1978]) sekä niiden toteutumiseen Monty Pythonin komediassa. Charneyn komediamalli on erittäin käyttökelpoinen siksi, että se muistuttaa Wollenin vastaelokuvan mallia, vaikka suoraa yhteyttä siihen ei olekaan: Charneyn malli auttaa yhdistämään komedian ja ei-komediallisen toisiinsa. Seuraavaksi avaan tarkemmin Wollenin vastaelokuva-typologian ja sen suhteutumisen Monty Pythonin komediaan. Näin tarkastelu etenee kohti Wollenin teesien merkitystä komedian vastaelokuvallisuuden ymmärtämiselle, ei siitä poispäin. Koska mitään suoraa yhteyttä komedian ja vastaelokuvan välillä ei ole, näen tämän toimivimmaksi ratkaisuksi: vastaelokuva auttaa näin ymmärtämään komediaa olematta sen ymmärtämisen lähtökohta.

\section{Monty Python televisiosta elokuvaan}

Monty Python aloitti toimintansa vuonna 1969 BBC:n tilaamana sketsikomediasarjana Monty Pythonin Lentävä sirkus (Monty Python's Flying Circus, BBC, 1969-1974), joka sai rajallisista budjeteista huolimatta suuren taiteellisen vapauden. Ryhmä koottiin kasaan BBC:llä käsikirjoittajina ja esiintyjinä jo toimineista nuorista kyvyistä (Cleese 2014, 382-386). Eräs keskeinen komediallinen idea oli, että sketsit eivät noudata vakiomuotoa, jossa sketsi päättyy komedialliseen huipennukseen eli punch lineen, vaan perusideaksi tuli kerronnan rakenteiden rikkominen ja ennustamattomuus. Ryhmän esikuviin kuulunut Spike Milligan, The Goon Show -veteraani ja yksi toisen maailmansodan jälkeisen brittikomedian keskushahmoista, ehti aloittaa samalla idealla televisiokomedian Q5 (BBC, 1969-1982), mutta Pythonit pitivät kiinni ideasta.

Tämän lisäksi Lentävälle sirkukselle on ominaista - sarjan visuaalista ilmettä voimakkaasti hallitsevien Terry Gilliamin animaatioiden groteskin surrealis-
3 Sarah Street toteaa Wollenin teeseistä, että niille ominainen intertekstuaalisuuden, rajojen eroosion ja heterogeenisten diskurssien korostaminen olivat keskeisiä myös postmodernismille, ja täten niitä voi soveltaa myös 1970-luvun jälkeiseen elokuvaan (Street 1997, 213). Olen samaa mieltä.

4 David Bordwellin (1979, 716-724) mukaan taide-elokuva määrittää itsensä suhteessa klassiseen/Hollywoodin kerrontamuotoon ja erityisesti sen perustana olevaa syy-seuraus-rakennetta vasten. Lisäksi taide-elokuva on realismin ja yksilöllisen taiteellisen ilmaisun - Bordwell painottaa, että taide-elokuvaohjaajilla on omat yksilölliset tyylinsä - motivoimaa. Vaikka taide-elokuvassa esimerkiksi klassisen kerronnan tavat käsitellä aikaa ja tilaa voidaan haastaa ja ohjaaja (auteur) tuodaan etualalle, poikkeaa vastaelokuva kuitenkin selvästi taide-elokuvan "valtavirrasta". 
min ohella - television lähes ylitsevuotava läsnäolo mediana. Kuten Richard Topping korostaa, ennen Lentävää sirkusta BBC:n logon käyttö ja ohjelmakuulutukset, jotka ovat tärkeä osa ohjelman komediasisältöä, kuuluivat BBC:llä ainoastaan eri ohjelmien välisiin lähetyssegmentteihin (Topping 20007, 25). Esimerkiksi eräässä jaksossa sketsien välissä ruudulle ilmestyy BBC1:n logo ja ohjelmakuulutus, jossa kerrotaan BBC2:lla alkavasta paneelikeskustelusta. BBC1:1lä puolestaan katsojille tarjotaan "minä kertomassa teille tämän" ("On BBC1, it's me telling you this") (Lentävän sirkuksen jakso 17, ensiesitys lokakuussa 1970). Lisäksi, vaikka television perusluonteeseen kuuluu eri medioiden sisällön käyttö, mukaan lukien niiden parodiointi (ks. esim. Stokes 1999, 168-186), ja television ohjelmavirta koostuu useiden narratiivien virrasta, joista monet ovat "keskeneräisiä" (Abercrombie 1996, 23), Lentävän sirkuksen televisiomotiivien käyttö ja niiden käsikirjoitettu "keskeneräisyys" tekevät näkyväksi ja parodioivat televisiokonventioita vastaelokuvan periaatteiden kaltaisesti. ${ }^{5}$

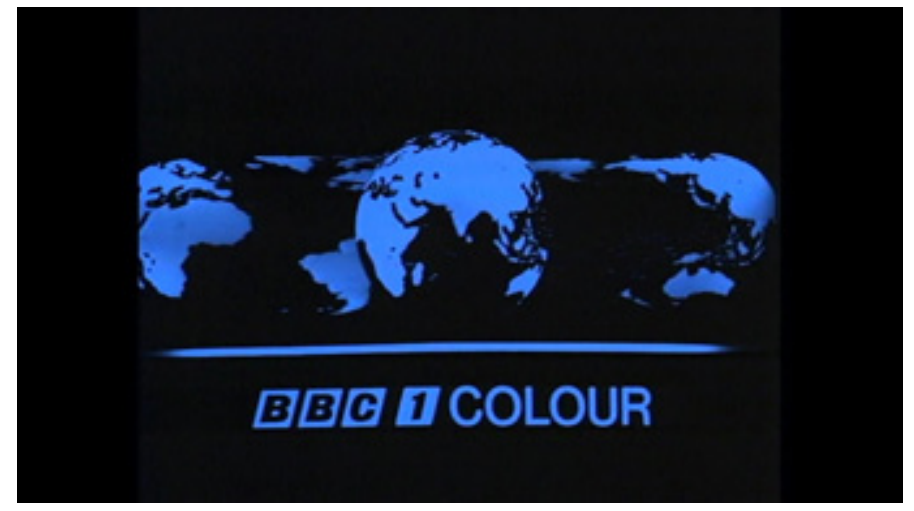

BBC:n logon käyttö on tärkeä osa Lentävän sirkuksen komediasisältöä. Kuva: kuvakaappaus DVD:Itä.

Tärkeä edeltäjä Lentävän sirkuksen televisuaalisuutta korostavalle tyylille oli David Frostin isännöimä satiirinen That Was the Week That Was (BBC, 1962-1963), jonka ideana oli luoda televisiostudiosta eräänlainen "viileä" klubi tai "mesta", jossa mikään - mukaan lukien televisioteknologia - ei ollut piilotettua (Briggs 1979, 217-221). Monty Pythonia välittömästi edeltänyt Do Not Adjust Your Set (ITV, 1967-1969), jossa mukana oli myös tulevia Pythoneita, oli taas nimensä mukaisesti sketsikomedia, joka leikitteli televisiolla mediana. Television rooli Lentävässä sirkuksessa on kuitenkin edeltäjiinsä verrattuna niin voimakas, että sarjasta voi puhua "televisiona televisiosta" (Mähkä 2016, 43-60). Sketsit hyödyntävät, käsittelevät tai sekoittavat keskenään lähes kaikkia tuon ajan ohjelmatyyppejä ja -formaatteja uutisista, ajankohtaisohjelmista ja makasiineista saippuaoopperaan, lastenohjelmiin ja televisiovisailuihin (ks. myös Neale 2001; Landy 2005). Uutta ja innovatiivista Lentävässä sirkuksessa oli BBC:n, eli sarjan tuottajan ja lähettäjän, tuominen mukaan osaksi komediaa.

Monty Pythonin Hullu maailma on Monty Pythonin neljästä elokuvasta selkeimmin vastaelokuvallinen. Tämä selittynee osittain sillä, että kyseessä oli ryhmän toinen kokoillan elokuva. Ensimmäinen oli Elämä on Pythonia (And Now for Something Completely Different, Ian McNaughton, Iso-Britannia 1971), joka oli kokoelma Lentävän sirkuksen sketsejä filmille uudelleen kuvattuna kansainvälistä teatterilevitystä varten. Siksi televisiokomediassa käytetyt tekniikat siirtyivät kunnianhimoisista tuotantoarvoista huolimatta myös ryhmän ensimmäiseen näytelmäelokuvaan. Kuten Terry Jones on todennut,

5 Raymond Williams toteaa aikalaistutkimuksessaan, miten Lentävä sirkus loi uudenlaisia visuaalisia vitsejä television konventioista "vain vaihtamalla äänensävyä ja näkökulmaa" (Williams 1975, 76). 
mediatietoisen komedian tekeminen myös Hullussa maailmassa oli ainakin osittain tietoinen ratkaisu (sit. Morgan 1999, 147-148).

Ryhmän seuraava elokuva eli Brianin elämä (Monty Python's Life of Brian, Jones, Iso-Britannia 1979) sisältää oikeastaan vain yhden kohtauksen, jonka voi tulkita vastaelokuvalliseksi, ${ }^{6}$ eikä piirrettä ole juuri heidän viimeisessäkään elokuvassaan Elämän tarkoitus (Monty Python's Meaning of Life, Jones ja Gilliam, Iso-Britannia 1983). Tässä artikkelissa käsitellään näin Lentävän sirkuksen sketsejä ja elokuvaa Hullu maailma. Television ja elokuvan välinen kulttuurinen ero tulee selvimmin esiin Hullun maailman aikalaiskritiikissä, mutta varsinaista eroa vastaelokuvallisen komedian esiintymiselle Monty Pythonin tuotannossa en pyri rakentamaan edellä mainitusta syystä: ryhmä ennen kaikkea siirsi mediatietoisen komediansa televisiosta elokuvaan. Yleisten vastaelokuvallisten piirteiden luetteloinnin sijaan avaan niitä konkreettisten sketsien ja elokuvaotosten analyysin yhteydessä alla.

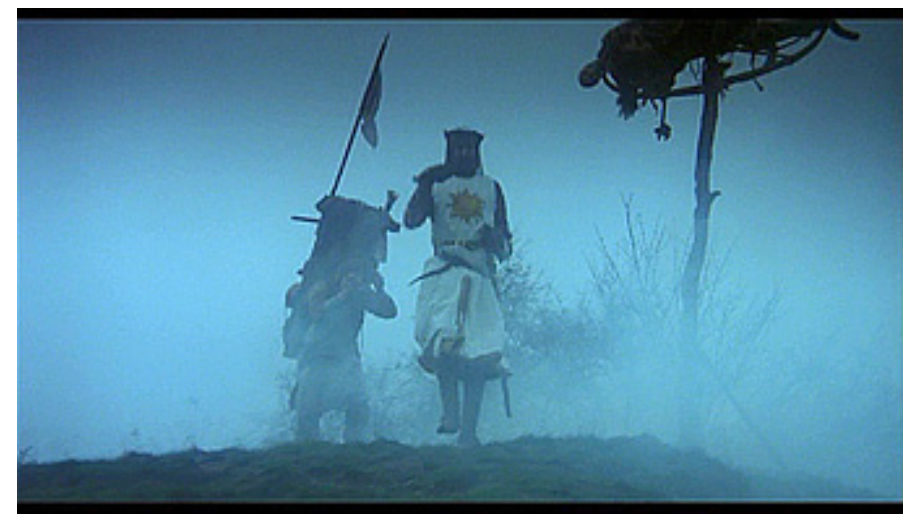

Hullussa maailmassa mimeettinen eheys rikkoutuu heti alkusekunneilla, kun sumusta "ratsastaa" esiin ritareita ilman hevosia. Kuva: kuvakaappaus DVD:Itä.

\section{Vastaelokuva-käsitteen historia}

Kevään 1968 poliittinen kuohunta Ranskassa haastoi nuoret vasemmistolaiset elokuvantekijät ajattelemaan taiteenlajin perusajatuksia uudelleen, jotta myös elokuva voisi osallistua yhteiskunnan muuttamiseen. Kuten Pam Cook huomauttaa, prosessi lähti liikkeelle tavanomaisen auteur-keskeisesti. Artikkelissaan Wollen valitsi ranskalaisista ohjaajista vastaelokuva-käsitteensä selittämiseen Godardin, joka edusti esimerkillistä materialistista vastaelokuvaa (Cook 2007, 467). Butlerin mukaan Godardilla on elokuvantekijänä monimutkainen poliittis-teoreettinen intellektuaalinen tausta (Marx, Mao, Saussure, Lacan, Althusser), mutta hänen vastaelokuvallinen strategiansa pohjautuu paljon selkeämmin Brechtin ja Eisensteinin ideoiden kehittelylle. Ensin mainitulta Godard omaksui etäännyttämisen ja katsojan samastumisen estämisen tavoitteenaan johdattaa tämän huomio laajempiin sosiaalisiin kysymyksiin. Eisensteinin montaasitekniikkaa Godard puolestaan siirsi kuvien konfliktin sijasta koodien sekä merkitsijän ja merkityn välisiin konflikteihin (Butler 2007, 92-93; ks. myös Cook 2007, 467-468). Tärkeä vaikuttaja Godardille oli myös neuvostoliittolainen dokumenttielokuvan pioneeri Dziga Vertov, jonka mukaan Godard ja Jean-Pierre Gorin nimesivät vuosina 1967-1972 toimineen vasemmistoradikaalin "spontaanis-dogmaattista" elokuvaa tehneen ryhmittymän Le Groupe Dziga Vertov (Lesage 1983).

Wollenin ensimmäinen kirjoitus vastaelokuvasta on vuodelta $1972,{ }^{7}$ ja sen perusajatus on näennäisen yksinkertainen: koska Hollywood-elokuva 
on muodostanut ne hallitsevat koodit, joilla elokuvaa luetaan, vain vastakkainasettelu Hollywoodin kanssa voi tuottaa jotain uutta (Cook 2007, 467). ${ }^{8}$ Wollenin kirjoituksen jälkeen vastaelokuvakirjoittelussa nostettiin esiin Brecht ja tämän "eeppinen teatteri", jonka perusajatukset vastaelokuvalliset ohjaajat omaksuivat: teatteriteknologian näkyväksi tekeminen, katsojan suora puhuttelu, anti-illusorisuus, katsojan vieraannuttamisen ajatus. Mielenkiintoista on, että teatteritutkija J. L. Styan kirjoitti 1960-luvun alussa "eeppisessä teatterissa" asioiden koomisen käsittelyn tendenssistä, jolla estettiin katsojan samastuminen näytelmän hahmoihin, sillä samastuminen estää ajattelemasta. Silti oli oleellista, että suoraviivaista koomista vääristämistä oli vältettävä. (Styan 1962, 187-193.) Brechtin tekniikoista olivat tietoisia niin taide-elokuvan tekijät kuin Monty Pythonkin. ${ }^{9}$ Yksi keskeinen yhteinen ominaisuus Brechtin, taide-elokuvan ja Monty Pythonin välillä on episodimaisuus, josta Pythonien elokuvia kritisoitiinkin. ${ }^{10}$ On huomattavaa, että Styan piti "eeppisen teatterin" teatteriin tuomana todellisena uutuutena juuri episodimaista rakennetta.

Dana B. Polan kirjoitti vasta perustettuun Jump Cut -lehteen vuonna 1974 sen aikaisesta elokuvateorian "illusionismin kritiikistä", johon liittyy myös Brechtin löytäminen uudelleen. Toisaalta Brecht nähtiin nyt formalistina, toisaalta realistina. Joka tapauksessa Polan, joka syyttää Wollenin kirjoituksia tietystä epämääräisyydestä ideologian ja varsinaisen elokuva-analyysin suhteiden välillä, näki, että kyseessä oli hyökkäys elokuvan vallitsevia kerronta- ja representaatiomuotoja vastaan (Polan 1974). Alan Lovellin samaan lehteen vuonna 1982 kirjoittamassa artikkelissa on eeppisen teatterin rinnalle päässyt vastaelokuva, ja Brecht ja Godard nimetään radikaalien nykyohjaajien poliittisen estetiikan perustaksi (1982). Mielenkiintoista on, että vastaelokuva on vakiintunut käsitteenä tavallaan jopa siinä määrin, että Wollenia ei edes mainita pitkähkössä artikkelissa.

Wollen kehitti ajatuksiaan pidemmälle niin ikään vuoden 1982 artikkelissaan "Godard and Counter-Cinema: Le Vent d'est", jossa hän taulukoi "Hollywood-Mos ${ }^{11}$-elokuvan seitsemän kuolemansyntiä ja vastaelokuvan seitsemän kardinaalihyvettä" (Wollen 1982, 79; ks. myös Butler 2007, 92). Näihin synteihin ja hyveisiin palataan tarkemmin alla. Yleisesti ottaen voi todeta, että vastaelokuvakeskustelu näyttää olleen ensi sijassa 1970-luvun ja 1980-luvun alun verrattain pienimuotoinen ilmiö, mikä on epäilemättä ainakin osin seurausta siitä, että vastaelokuva pysyi marginaalisena ilmiönä.

\section{Monty Python ja taide-elokuvan parodia}

Monty Python sekä otti vaikutteita eurooppalaisesta taide-elokuvasta että parodioi sitä. Ensin mainittuun piirteeseen palataan alla, sitä ennen on aiheellista nostaa esiin Lentävän sirkuksen parodiat. Sketsi "Pasolini's Third Test Match" (39, tammikuu 1973) parodioi Pier Paolo Pasolinin tyylin seksuaalista ja uskonnollista symboliikkaa sijoittaen sen peribrittiläiseen ympäristöön, krikettiotteluun. Sketsi "Salad Days" (33, marraskuu 1972) puolestaan parodioi amerikkalaisohjaaja Sam Peckinpahin tyyliteltyä väkivaltaa tahattomasti erittäin veriseksi muodostuvalla ylemmän keskiluokan piknikillä. "Peckinpahin uusinta elokuvaa", siis tuota sketsiä, ylistävä BBC:n elokuvamakasiinin juontaja (Eric Idle) saa "ansionsa" mukaan, sillä hänet ammutaan seulaksi hidastuksia ja hyppyleikkauksia - Peckinpahin ja uuden aallon eurooppalaisen elokuvan vakiotekniikoita - käyttäen.
8 Godard kollegoineen ihaili uransa alkupuolella Hollywoodia ja sen ohjaajia, mutta yllä mainittu 1960-luvun eurooppalaisen ja erityisesti ranskalaisen elokuvan politisoituminen yhteiskunnallisessa kuohunnassa asettivat lähes automaattisesti vasemmistolaiset taiteilijat Hollywoodin vastapooliksi. Ohjaajien mielipiteet vaihtelivat: Truffaut halusi uudistaa valtavirran elokuvaa, kun taas Godardin suhde siihen muuttui peräti vihamieliseksi. (Ks. esim. Martin 2013, 44-45.)

9 Hoffmanin mukaan Pythonit tunsivat Brechtin teoriat mutta eivät omaksuneet niitä suoraan tämän teatterista (Hoffman 2002, 145). Thompson puolestaan pohtii, olivatko Pythonit "brechtiläisiä" päätyen väittämään, että eivät missään tapauksessa (Thompson 1982, 30-31). Syy Thompsonin mukaan on se, että Pythonit pyrkivät vain hauskuuttamaan yleisöjään.

10 Hoffman esittää radikaalilta tuntuvan väitteen: Hullun maailman episodit voisi vapaasti laittaa uuteen järjestykseen merkitysten siitä kärsimättä (Hoffman 2002, 143).

11 Wollen ei tarkenna, mitä hän "mos"-sanalla tarkoittaa, mutta yleensä se viittaa ilman ääntä kuvattavaan otokseen. Yleisen käsityksen mukaan kyseessä on lyhenne sanoista "mit out sound", jolla Hollywoodiin siirtyneet, heikosti englantia osanneet saksalaisohjaajat ohjeistivat henkilökuntaansa kuvauspaikalla. Wollen painottanee tällä ennen kaikkea valtavirran elokuvan yksidiegeettisyyttä suhteessa vastaelokuvan monidiegeettisyyteen: elokuvassa tai sen yksittäisessä otoksessa ei ole keskenään kilpailevia tai toisilleen vastakkaisia diskursseja. 

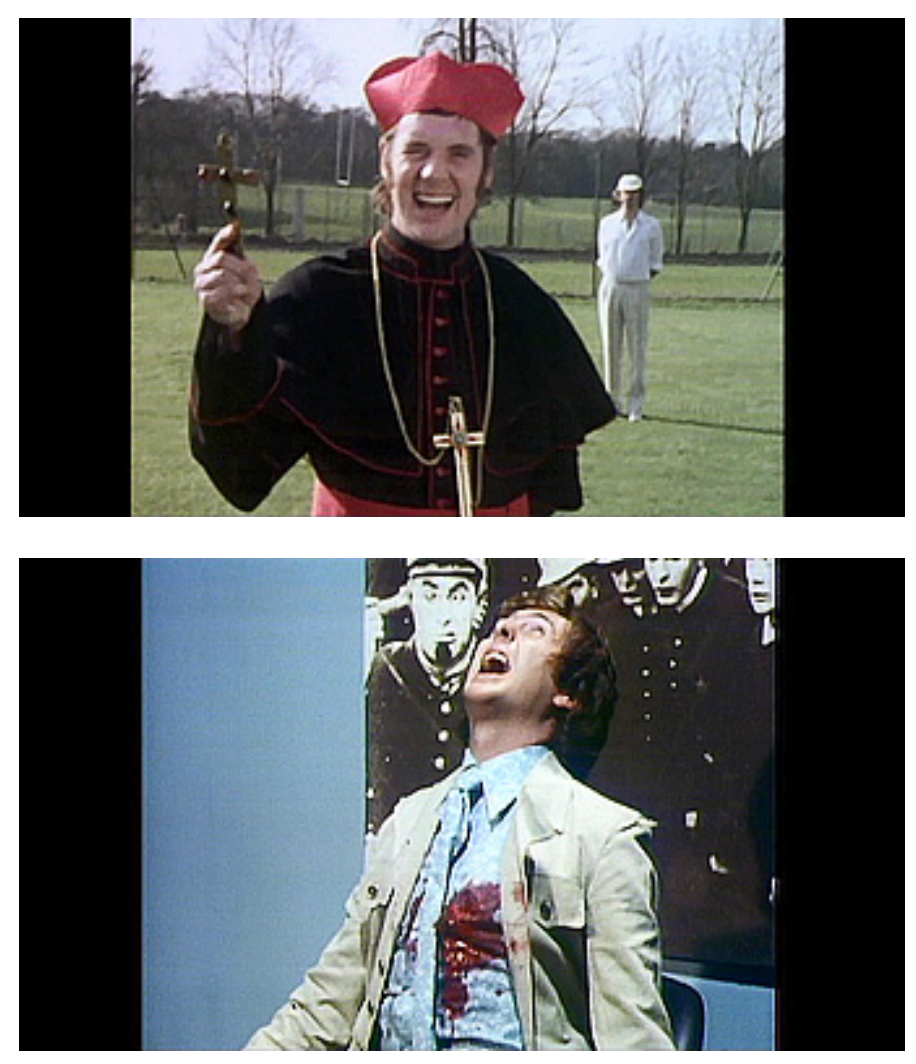

Sketsit "Pasolini's Third Test Match" ja "Salad Days" parodioivat taide-elokuvan tyylejä ja tekniikoita. Kuvat: kuvakaappauksia DVD:Itä.

Sketsi "French Subtitled Film" (23, joulukuu 1970) parodioi Godardin ja muiden ranskalaisten uuden aallon auteurien tyyliä. Käsivaralla kuvattu kohtaus sijoittuu kaatopaikalle. Äänimaailmaa hallitsevat jätekasojen yllä kiertelevät lukuisat lokit. Savuketta poltteleva mies (Jones) ja tuolilla kaali sylissään istuva nainen (Cleveland) aloittavat väkinäisen ja töksähtelevän ranskankielisen small talkin. Yhtäkkiä mies kävelee kuvaruudun ulkopuolelle, palaa ja ilmoittaa olevansa vallankumouksellinen. Tästä mielenkiintoisesta paljastuksesta huolimatta keskustelu ei lähde liikkeelle. Seuraa leikkaus televisiostudioon, jossa englantilainen makasiiniohjelman isäntä (Idle) kertoo, että elokuva, josta juuri näimme katkelman, kuvaa "kommunikaation katkeamista modernissa yhteiskunnassa", ja elokuva myös "paljastaa armotta yhteiskuntamme perustana olevan väkivallan".

"Elokuvasta" seuraa toinen katkelma, joka selvästikin liittyy juontajan jälkimmäiseen näkemykseen väkivallan paljastamisesta. Dialogi jatkuu päämäärättömänä, ja sitä taltioiva ekstradiegeettinen mikrofoni näkyy hetken kuvan yläreunassa. Seuraa montaasijakso, jossa vuorotellaan kaatopaikkaotosten, mustavalkoisten sotakuvastoa ja mellakoita sisältävien arkistofilminpätkien sekä niin ikään mustavalkoisten, Pythonien näyttelemien slapstick-väkivaltaotosten välillä. Viittaukset Vietnamin sotaan (helikopteri tulittamassa viidakkomaiseman yllä) ja opiskelijalevottomuuksiin Atlantin molemmin puolin näyttävät selkeiltä. Arkistofilmien kavalkadi päättyy otokseen atomipommin räjähdyksestä. Kuva siirtyy kaatopaikalle, jossa alkaa kuulua kellon tikitystä. Mies ja nainen katselevat hämmentyneinä ympärilleen. Naisen sylissä oleva kaali räjähtää, todennäköisesti surmaten protagonistiparin, ja elokuva loppuu. Räjähdys kuvataan eri kuvakulmista ja eri etäisyyksiltä normaalin jatkuvuuden rikkovin hyppyleikkauksin. Sketsi parodioi varsinkin Godardin mutta 

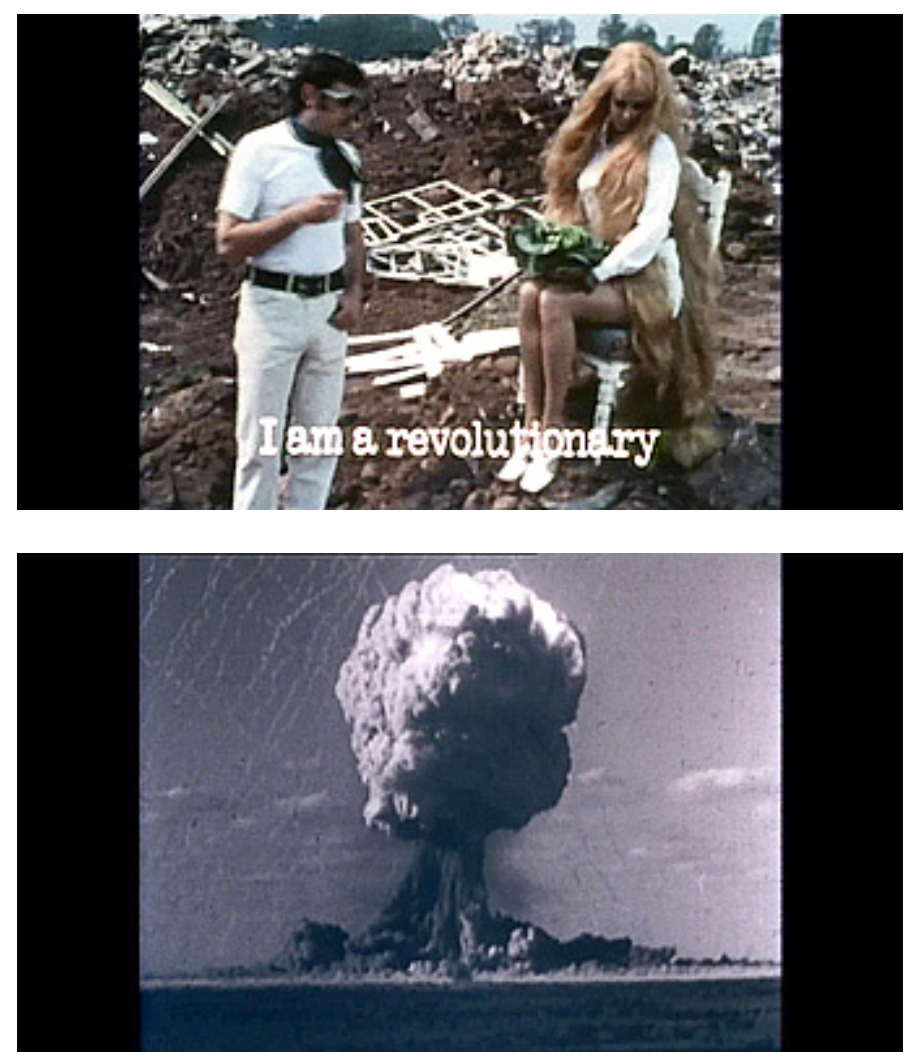

Sketsi "French Subtitled Film" parodioi Godardin ja muiden ranskalaisten uuden aallon auteurien tyyliä. Kuvat: kuvakaappauksia DVD:Itä.

ylipäätään uuden aallon ohjaajien tekniikoita, kuten luonnonvalon käyttöä, käsivarakameraa ja improvisoitua dialogia (Godardin ja uuden aallon tekniikoista ks. Fabe 2004, 132-134; Neupert 2007, 166-168; Martin 2013, 44-48).

Vastaelokuvan käsitettä avattaessa parodia on keskeinen rinnakkainen tekniikka. Parodia paljastaa kohteensa tyylilliset ja sisällölliset konventiot hauskuuttamismielessä, ja onkin tärkeää painottaa parodian kohteestaan etäännyttävää, tiettyyn paradoksaaliseen ylemmyydentunteeseen perustuvaa luonnetta. Linda Hutcheon korostaa, että parodialla on aina kriittinen suhde kohteeseensa (Hutcheon 1985, 15, 20, 32, passim.). Hutcheonia kritisoidessaan Dan Harries väittää, että parodiset tekstit luovat yhtä aikaa samankaltaisuutta ja eroavuutta tuottavan diskurssin suhteessa kohteeseensa, eikä näiden välille voi luoda hierarkkisesti muotoutuvaa suhdetta (Harries 2000, 8). Olen kuitenkin samaa mieltä Hutcheonin kanssa, sillä huolimatta komedian alemmasta statuksesta suhteessa draamaan - draaman ja komedian välisen hierarkian loi Runousopissaan jo Aristoteles ja, kuten alla käy ilmi, myös Pythonit olivat tästä tietosia - parodia katsoo väistämättä kohdettaan alaviistoon, sillä muussa tapauksessa se ei voi toimia parodiana ja komediana. Huumorin ylemmyysteorian mukaisesti humoristinen moodi, kuten komedia, edellyttää kohteensa ainakin hetkellistä yläpuolelle asettumista (ks. esim. Billig 2005, 42-43; Stott 2005, 131-137). Vastaelokuva toimii parodian tavoin, sillä se paljastaa valtavirran elokuvan elokuvallisuuden, mutta se ei pyri tekemään kohdettaan naurunalaiseksi.

Eurooppalainen uuden aallon elokuva ja laajemmin taide-elokuva ylipäätään inspiroi Monty Pythonia muutenkin kuin vain parodian kohteena. ${ }^{12}$ Erona on, että Monty Python on komediaa, mutta on tärkeää nostaa esiin samankaltaisuudet uuden aallon elokuvan ja Monty Pythonin välillä Monty Pythonin 
ymmärtämiseksi. Lähtökohtana on, että viimeksi mainittu ei ole "pelkkää" brittikomediaa. Pythonit tavoittelivat taide-elokuvan tasoa vastaavaa taiteellista ilmettä ja tuotantoa, mikä tulee parhaiten esiin heidän kunnianhimoisessa historiallisten periodien kuvauksessaan - on syytä painottaa, että ryhmän tunnetuimmat elokuvat, Hullu maailma ja Brianin elämä, ovat nimenomaan historiallisia komedioita.

Pythonin jäsen Michael Palin kirjoittaa julkaistussa päiväkirjassaan, että Hullua maailmaa suunnitellessaan he eivät halunneet tehdä elokuvaa "Carry On King Arthur" viitaten pitkäaikaiseen brittikomediaelokuvien sarjaan (Palin 2006, 163-164). Palin tarkoittaa sitä, että Carry On -elokuvissa tuotannollisiin arvoihin, kuten lavastukseen ja puvustukseen, panostettiin vain välttämätön, eivätkä elokuvat näin näyttäneet uskottavilta historialliselta ilmeeltään. Gilliam ehdotti, että Hullua maailmaa ajatellen ryhmä katsoisi Pasolinin Canterburyn tarinoita (The Canterbury Tales, Italia ja Ranska 1972), ja Palinin päiväkirjamerkinnästä päätellen kaikki olivat vakuuttuneita italialaisohjaajan työstä: he pyrkisivät samankaltaiseen keskiaikaisen Englannin uudelleenluomiseen valkokankaalle, samantasoisella elokuvataiteellisella otteella (ibid.). Muita Pythonien haastatteluissaan mainitsemia innoittajia olivat muun muassa Truffaut, Kubrick ja Bresson (Gow 1974, 17; Rubinstein 1985, 7). ${ }^{13}$

Pythonien perusideana oli, että rakentamalla mahdollisimman uskottavan epookin ja esittämällä komediaa sitä vasten elokuvasta tulisi mahdollisimman hauska (Morgan 1999, 164-171). Ryhmän onnistumista kuvaa se, että aikalaiskritiikissä mainittiin Pasolinin ohella Fellinin, Kurosawan ja Eisensteinin kaltaisia ohjaajasuuruuksia (Gow 1975, 40; Stuart 1977, 38; ks. myös Morgan 1999, 272-273). Films and Filming -lehden Gordon Gow oli eräs kriitikoista, joka kirjoitti, että "asiayhteydestään irrotettuna" elokuvassa oli sama eeppisen draaman laatu kuin elokuvissa, joita Hullu maailma parodioi (Gow 1975, 40). Voidaan melko suurella varmuudella olettaa, että "asiayhteys" viittaa komediaan - lajityyppiin, jota sittemmin huomattavan uran ohjaajana tehneen Gilliamin mukaan ei oteta vakavasti elokuvanteosta keskusteltaessa. Hän toteaa, ehkä tietoisena yllä kuvatusta Monty Pythonin elokuvien kritiikistä, että ryhmä leikitteli paikoin jopa vallankumouksellisesti elokuvalla mediana mutta ei saanut siitä kiitosta, päinvastoin kuin televisiokomedian tapauksessa (sit. Morgan 1999, 314). ${ }^{14}$

Onkin syytä pitää mielessä keskeiset erot television ja elokuvan välillä, sillä, kuten edellä todettiin, kamerat, mikrofonit ja muu lähetysteknologia ovat osa televisioestetiikkaa, mutta elokuvaan ne eivät perinteisessä mielessä kuulu, elleivät ne ole osa elokuvan diegeettistä maailmaa. Toisekseen, elokuvan prestiisi on aivan eri tasolla kuin television - päinvastoin kuin elokuva, televisio ei ole taidetta. ${ }^{15}$ Siksi on mielenkiintoista tarkastella Hullun maailman aikalaiskritiikkiä, jossa prestiisiero television ja elokuvan välillä tulee hyvin esiin. Pääsääntöisesti elokuvan epookkia ylistetään, kun kovin kritiikki taas kohdistuu Lentävästä sirkuksesta tuttuun poukkoilevaan ja tarinankerrontaa rikkovaan komediaan, josta osa on selvästi vastaelokuvallista, vaikka aikalaiskriitikot eivät sanaa käytäkään.

Monthly Film Bulletinin Geoff Brown pitää elokuvaa täysin yliampuvana. Häntä ovat häirinneet jo elokuvan alkutekstit, ja erilaiset visuaaliset ja verbaaliset gagit on hänen mielestään vain laitettu peräkkäin vailla toimivaa ajoitusta tai rakennetta. Brown toteaa, että se, mikä toimii hyökkäyksenä perinteistä sketsikomediaa vastaan televisiossa ja television fragmentaarisuuden "nerokkaana" väärinkäyttönä - viitaten siis Lentävään sirkukseen -, on epähedelmällistä elokuvassa (Brown 1975, 84-85). Viimeinen kommentti
13 Truffaut on provokatiivisesti todennut, että sanojen "elokuva" ja "Britannia" välillä on tietty yhteensopimattomuus (sit. Caughie and Rockett 1996, 1, 7-8). On mahdollista, että Pythonit olivat tietoisia ranskalaisten asenteista ja tämä osaltaan inspiroi heidän taide-elokuvaparodiaansa.

14 Taide-elokuvan ja komedian arvostusten epäsuhtaan liittyen Gilliam on haaveillut "Cahiers du Comedy" -lehdestä, mutta turhaan. Hän on myös todennut, että monille Monty Python oli 1970-luvun brittielokuva, mutta ei Britanniassa (McCabe 1999, 57; Morgan 1999, 314). Mielenkiintoista kyllä, Gilliamin kritisoima brittiläinen elokuvatutkija Alexander Walker ei tosiaankaan kirjoita paljoakaan Monty Pythonista 1970- ja 1980-lukujen brittielokuvaa käsittelevässä kirjassaan National Heros (1985) mutta toteaa ryhmän ja Derek Jarmanin olevan kaksi omaperäisintä kykyä Britanniassa (Walker, ei sivua).

15 Lynn Spiegel kirjoittaa CBS:n yrityksestä nostaa television arvostusta Yhdysvalloissa perustamalla aikakauslehti televisiokritiikille ja kutsumalla Oxbridge-koulutettuja brittikriitikoita sen kirjoittajiksi. Aikakauslehteä ei syntynyt, mutta hanke tuotti kirjan nimeltä The Eight Art (1962) (Spiegel 1998, 67-69). Kirjan nimi viittaa tietysti elokuvaan seitsemäntenä taiteena, mutta "kahdeksannen taiteen" asemaa televisio ei ole ainakaan toistaiseksi saavuttanut. 
on nähtävissä nimenomaan mainittuna television ja elokuvan kulttuurisen mieltämisen erona. Niinpä on loogista, että MFB:n Clyde Jeavons kiittelee Monty Pythonin seuraavaa elokuvaa eli Brianin elämää (1979) siitä, että ryhmä on ymmärtänyt hylätä televisio-ohjelmansa fragmentaarisen absurdiuden, joka vain häiritsee 90 minuutin näytelmäelokuvan tahtia (Jeavons 1979, 229). On kuitenkin syytä paneutua seuraavaksi huomattavasti Wollenin vastaelokuvan typologiaa muistuttavaan komedian erityispiirteiden hahmotteluun, sillä ne auttavat ymmärtämään Monty Pythonin komedian vastaelokuvallisuutta.

\section{Charney, komedian erityispiirteet ja vastaelokuvallisuus}

Kun eritellään, mitä yhtäläisyyksiä ja eroja ei-komediallisella ja komediallisella vastaelokuvalla on, on hyödyllistä tarkastella Maurice Charneyn luomaa komedian kuuden erityispiirteen listaa (Charney 1987, 5-7). Piirteet ovat osin päällekkäisiä ja toisiaan määrittäviä, mutta yhtä kaikki erittäin käyttökelpoisia artikkelin problematiikan ja johtopäätösten ymmärtämiselle. Ensimmäinen piirre on "epäjatkuvuus" (the discontinuous), mikä tarkoittaa rationaalisen järjestyksen ja kausaliteetin rikkomista. Toinen on "sattumanvaraisuus" (the accidental), jolla viitataan komedian epäjohdonmukaisuuden piirteen merkityksen ymmärtämiseen koomisen kokemuksessa. Kolmas piirre on "autonomisuus" (the autonomous), jolla tarkoitetaan erillisten, toisistaan riippumattomien asioiden rinnakkain asettamista, jolloin ne voivat kommentoida tai valottaa toisiaan. Neljäs piirre on "itsetietoisuus" (the self-conscious), joka on "intensiivistä ja perinpohjaista" tietoisuutta ruumiista, jonka seurauksena ihmisruumis koetaan "luonnostaan koomiseksi". Viidenneksi, komedia on "näyttelijämäistä" (the histrionic), mikä viittaa komedialle yleiseen irrationaaliseen tai absurdiin esittämiseen. Viimeinen piirre on "ironinen" (the ironic), mikä viittaa merkitysten ambivalenssiin ja niiden mahdollisesti sanottua vastakkaiseen tarkoitukseen.

Suurin osa näistä piirteistä on löydettävissä Lentävän sirkuksen sketsistä "The Funniest Joke in the World" (1, lokakuu 1969), jossa on lisäksi käytössä monia Monty Pythonin komedialle tyypillisiä vastaelokuvallisia tekniikoita. Sketsi alkaa asuintalon työhuoneeseen sijoittuvalla otoksella, jossa mies (Palin) istuu kirjoittamassa. Ekstradiegeettinen kertojaääni (Cleese) esittelee miehen: kyseessä on "vitsienkirjoittaja" Ernst Scribbler, joka kohta keksii maailman hauskimman vitsin ja tulee kuolemaan nauruun sen seurauksena. Sama kohtalo odottaa miehen äitiä, joka tulee seuraavaksi vitsin lukemaan. Kertoja on oikeassa, ja molemmat henkilöt todellakin kaatuvat koomisesti ylinäyteltynä maahan katsojan silmien edessä. Tämä on selvä vastaelokuvallinen tekniikka: kertoja ei kerro, televisiodokumenteille ominaisesti, taannehtivasti ruudulla nähtyä, vaan hän avaa reaaliajassa tapahtumien kulkua tietäen jo ennen Scribbleriä, mitä tulee tapahtumaan. Vaikka kertojaääni olisikin lisätty filmiin jälkikäteen, mikään otoksessa ei viittaa siihen, että tapahtuma olisi lavastettu. Televisioryhmä siis ikään kuin sattuu olemaan paikalla, eivätkä kuvatut henkilöt näytä olevan kameran läsnäolosta mitenkään tietoisia, mikä on mahdollista viime kädessä siksi, että kyseessä on komedia. Charneyn komediapiirteistä otoksessa toteutuvat "sattumanvaraisuus" - televisioryhmän paikallaolo sekä "itsetietoisuus" ja "näyttelijämäisyys" eli hahmojen slapstick-tyylinen näytteleminen (sama piirre on ilmeinen kaikkien vitsin lukuisten uhrien kohdalla sketsin jatkuessa).

Kymmenminuuttinen sketsi jatkuu televisiodokumentin ja uutisraportoinnin sekoituksena liikkuen ajassa edestakaisin nykypäivän (1960-luvun 
lopun) ja menneisyyden (toisen maailmansodan) välillä noudattaen Monty Pythonin komedialle yleistä temporaalista ja spatiaalista vapautta (Mähkä 2016, 141-157). Samalla se vastaa Charneyn ajatusta komedian rationaalisen järjestyksen ja kausaalisuuden rikkovasta "epäjohdonmukaisuudesta". Britannian armeija kiinnostuu pian "tappajavitsiksi" nimetystä löydöksestä, mikä on sekä absurdia että loogista. Charneyn "autonomisuus" toteutuu tässä siten, että vitsien kirjoittaminen ja sotavoimien mahdollisimman tehokkaiden aseiden kehittely eivät normaalisti assosioidu toisiinsa. Lisäksi Charneyn komedian epäjohdonmukaisuutta korostavan termin "sattumanvaraisuus" rinnalle voi tässä nostaa Jerry Palmerin ajatuksen, jonka mukaan komediaa (ja huumoria) ohjaa "absurdin logiikka", eli komedialta ja huumorilta hyväksytään ja odotetaan erilaista loogisuutta kuin vakavilta moodeilta (Palmer 1987). Mikäli vitsin kuuleminen tappaa kaikki kuulijansa, armeija on "tietenkin" kiinnostunut sen käytettävyydestä.

"The Funniest Joke in the World" sisältää myös hauskan vastaelokuvallisen gagin, joka viittaa niin väkivaltaviihteen tuottamiseen kuin natsien kaltaisten stereotyyppien esittämiseen. Saksalaiset yrittävät saada brittivangin (Palin) paljastamaan "tappajavitsin". Cleesen esittämä SS-upseeri kovistelee brittiä, mutta tämä ei suostu kertomaan vitsiä. Kun britti vielä uhmakkaasti survaisee saappaansa upseerin varpaille keksimänsä vitsin huipentumana, viimeksi mainittu antaa käskyn seurassaan olevalle Gestapon miehelle (Graham Chapman). Kun Cleesen esittämä upseeri lyö brittiä kasvoille, Chapmanin hahmo lyö Cleesen lyönnin impaktihetkellä omat kätensä yhteen aiheuttaen terävän läimähtävän äänen. Tämä toistuu muutaman kerran. Toisin sanoen Gestapon mies tuottaa ääniefektin SS-miehen lyönnille viitaten komediallisella vastaelokuvallisella tekniikalla televisio- ja elokuvaväkivallan keinotekoisuuteen: Cleese ei oikeasti lyö Palinia. Ei-komediallisessa valtavirran elokuvassa vastaava tilanne pyritään tietysti esittämään mahdollisimman uskottavasti, vaikka katsojan ajattelisikin ymmärtävän väkivallan olevan näyteltyä. Sketsin ääniefekti-gagin voi tosin ymmärtää myös viittauksena slapstick-komedian elokuvaa edeltävään historiaan. ${ }^{16}$

Sketsin kuulustelukohtauksessa on itse asiassa ollut alusta asti toinen, vähintään yhtä selkeä vastaelokuvallinen elementti. Chapmanin esittämän Gestapo-upseerin kaulassa nimittäin roikkuu kyltti, jossa lukee "A Gestapo Officer", ja varmuudeksi siinä on myös nuoli, joka osoittaa kohti miehen kasvoja. Kuten katsoja ehkä ehtii arvata, natsit kuolevat nauraen, kun britti viimein kertoo "tappajavitsin" kiduttajilleen. Seuraavassa kohtauksessa saksalaiset tiedemiehet esittelevät kehittelemiään tappajavitsiehdokkaita saksalaiskenraalille (Jones), jonka vieressä seisoo Chapman, samassa rooliasussa kuin

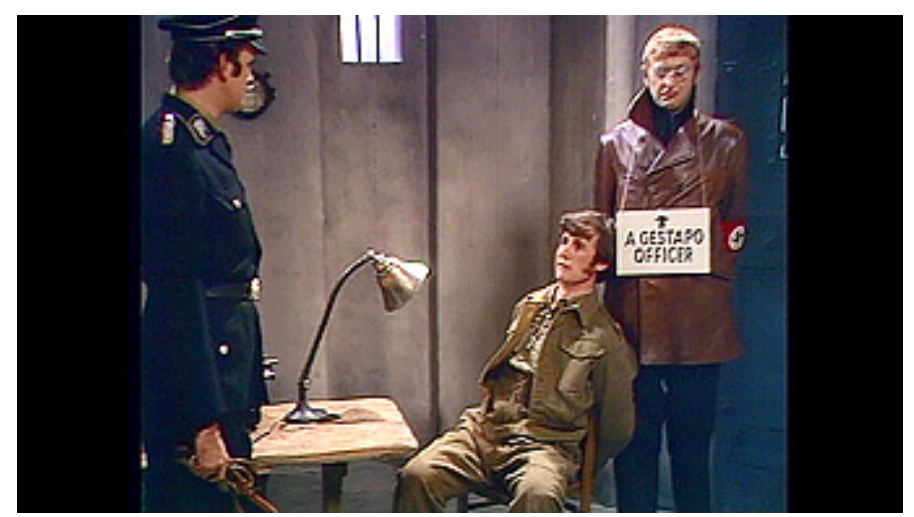

"The Funniest Joke in the World" -sketsin yksi näkyvimmistä vastaelokuvallisista elementeistä on Gestapo-upseerin kaulassa roikkuva kyltti, jossa lukee "A Gestapo Officer". Kuva: kuvakaappaus DVD:Itä.
16 Termi slapstick viittaa italialaiseen commedia dell'arte -komediaan, jolle oli leimallista liioiteltu fyysisyys. Näyttelijät mallinsivat törmäyksiä ja iskuja kuvaavat äänet erityisillä puisilla instrumenteilla, joihin on sittemmin viitattu juuri slapstick-nimellä. Varhainen elokuvakomedia ja toisaalta sen perinteitä jatkaneet koomikot, kuten amerikkalainen The Three Stooges, olivat farssille ja fyysiselle komedialle rakentuneen perinteen jatkajia (Bermel 1982, 22-23; Neale \& Krutnik 1990, 20-22; Chamberlain 2001, 53). Mykkäelokuvakomediasta puhuminen slapstick-komediana on siis tietyssä mielessä virheellistä. 
edellisessä kohtauksessa mutta nyt kaulassaan kyltti "A Different Gestapo Officer". Sen sijaan, että Pythonit olisivat vaihtaneet näyttelijää Chapmanista johonkin toiseen ryhmän jäseneen, he ovat siis tehneet vastaelokuvallisen $g a$ gin viihteelle ominaisesta stereotyypittelystä. On mielenkiintoista, että juuri nämä osat on jätetty pois sketsin Elämä on Pythonia -elokuvan versiosta, sillä voisi olettaa, että sen vastaelokuvalliset gagit olisivat olleet ymmärrettäviä - ja hauskoja - elokuvayleisöille.

Eräs vastaelokuvallinen sketsityyppi, joka toistuu läpi Lentävän sirkuksen, perustuu kuvateksteinä, dialogin yksittäisinä repliikkeinä tai visuaalisina gageina toteutetuille tekniikoille. Nämä viittaavat ekstradiegeettiseen, kuten lavastukseen tai näyttelijöiden astumiseen estradille, ja näkyvät hahmojen astumisena ulos rooleistaan ja takaisin sekä ohjaajan tai muun kuvaushenkilökunnan tunkeutumisena sketsin diegeettiseen maailmaan. Kaikissa on pohjimmiltaan kyse vastaelokuvan ytimestä eli katsojien muistuttamisesta siitä, että he katsovat elokuvaa. Siinä missä taide-elokuvan vastaelokuvallisuus on brechtiläistä katsojan tietoisuuteen vetoamista, Monty Pythonin komediassa ensisijainen tavoite on katsojien hauskuuttaminen vastaelokuvallisin keinoin. Esitän seuraavaksi kahden esimerkin avulla, miten tämä tapahtuu.

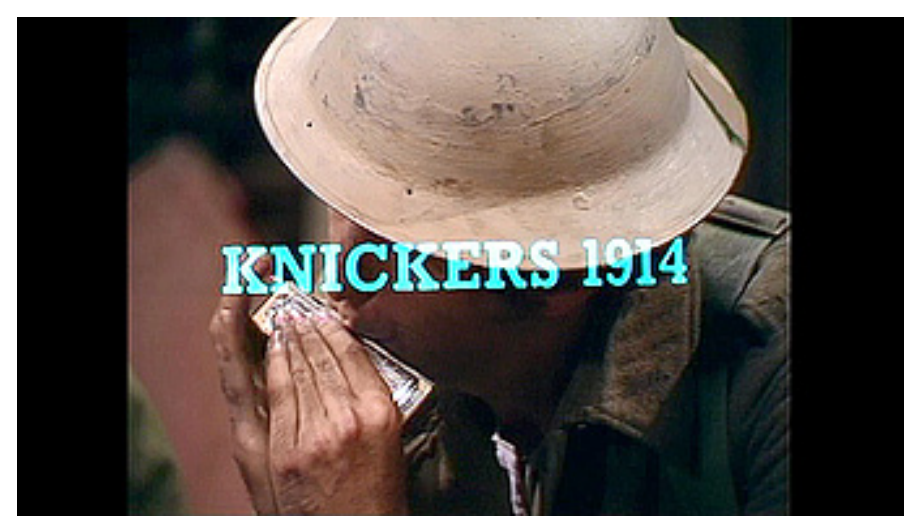

Virheellisillä tai vitsikkäillä kuvateksteillä leikkiminen on Monty Pythonin komedialle tyypillinen elementti, kuten "Ypres 1914" -sketsi paljastaa. Kuva: kuvakaappaus DVD:Itä.

Virheellisillä tai vain vitsikkäillä kuvateksteillä leikkiminen on Monty Pythonin komedialle tyypillinen elementti läpi heidän tuotantonsa. Esimerkiksi Hullu maailma paljastaa tällä tekniikalla satunnaisellekin katsojalle jo ennen varsinaisen elokuvan alkua, että kyseessä on komedia. Ensimmäisen maailmansodan juoksuhautoihin sijoittuva sketsi "Ypres 1914" (25, joulukuu 1970) sisältää useita yllä kuvattuja tekniikoita. Sen alkaessa katsojaa historiallisiin koordinaatteihin ohjaava kuvateksti "Ypres 1914" vaihtuu pikkutuhmaksi viittaukseksi naisten alushousuihin: "Knickers 1914". Ohjaaja komentaa "cut" ja seuraa uusi otto. Katsojan edes hetkellinen samastuminen estetään heti ekstradigeettisellä tekniikalla. Sketsi ei edisty tällä kertaa paljoa pidemmälle, ennen kuin ohjaaja päättää jälleen otoksen. Nyt häntä häiritsevät sketsiin kuulumattomat henkilöt, muun muassa astronautiksi pukeutunut näyttelijä. Kolmannella yrittämällä sketsi näyttää onnistuvan. Se kuitenkin loppuu siten, että eräs hahmoista, Cleesen esittämä sotilaspastori, aloittaa yhä vain paatoksellisemmaksi käyvän pitkän repliikin. Lopulta lääkintähenkilökunta hakee miehen studiolavasteista ja vie tämän ambulanssilla ylinäyttelemisen hoitamiseen erikoistuneeseen sairaalaan. 


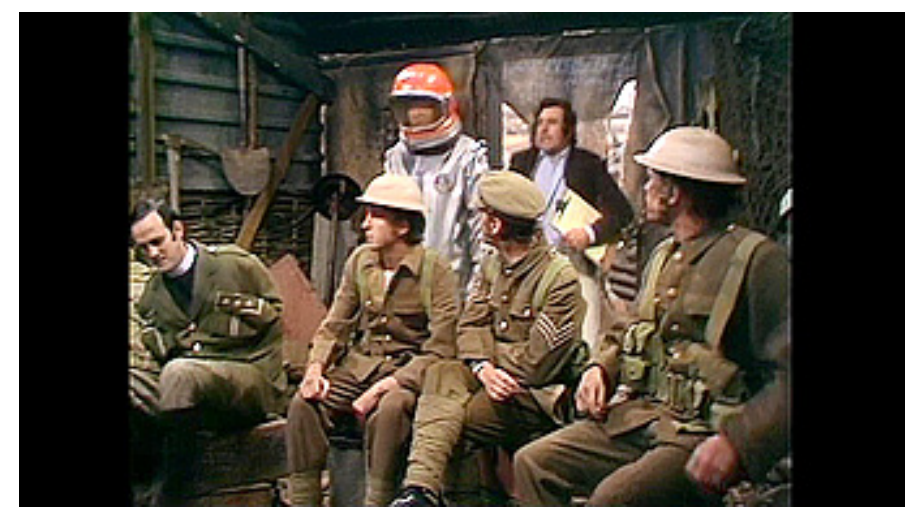

Ensimmäisen maailmansodan juoksuhautoihin sijoittuvassa "Ypres 1914" -sketsissä katsojan samastumista haittaa myös kuvaan työntyvä astronautiksi pukeutunut hahmo. Kuva: kuvakaappaus DVD:Itä.

Toisessa esimerkissä näyttelijöiden astumista ulos roolihahmoistaan käytetään televisioyleisöille suunnatun sisäpiirivitsin asiayhteydessä. Sketsi "The BBC Is Short on Money" (28, lokakuu 1972) alkaa pätkällä Titanicin uppoamisesta Roy Ward Bakerin klassikkoelokuvasta Titanicin kohtalonyö (A Night to Remember, Iso-Britannia 1958). Leikkaus johdattaa katsojat laivan komentosillalle, jossa päällystö antaa matkustajille pelastautumisohjeita laivan viestintäkanavan kautta. "Naiset ja lapset ensin" saa jatkoa yhä naurettavammiksi käyvän listan kautta, kun ensin pelastettavien joukkoon luetellaan astronautit, intiaanit ja "joko 1400- tai 1500-luvun flaamikauppiaat". Samaan aikaan päällystön jäsenet pukeutuvat paniikissa mainittuja ryhmiä vastaaviin asuihin, jotka ovat jostain saaneet käsiinsä. Miehet ovat päättäneet pelastautua merenkulun koodistosta välittämättä.

Sketsi jatkuu kuvatekstillä "muutamaa päivää myöhemmin". Laivan päällystö on viety eteläamerikkalaiselle poliisiasemalle kuulusteltavaksi. Pari miehistä kiistelee edelleen flaamilaisasun autenttisuudesta, kunnes yksi hyppää yhtäkkiä studiolavasteen ikkunan läpi. Epätoivoisen teon motiiviksi paljastuu, että toiminnallisista näyttelijäsuorituksista maksetaan paremmin kuin pelkästä passiivisesta statistiroolista. Kaikki ovat näyttelijöitä, jotka vain yrittävät tienata parhaansa mukaan budjetteja leikkaavalta BBC:ltä. Kyseessä on toistuva teema Lentävässä sirkuksessa: eräässä toisessa sketsissä budjetin kulumista seurataan kuvaruutuun ilmestyvien kuvatekstien avulla ("That's $£ 4.7 .6$ so far for the captions alone"), laivasketsissä taas BBC:n uutisankkuri kiistää huhut BBC:n talousvaikeuksista. Hän istuu vain yhden katosta roikkuvan hehkulampun valaisemassa studiokopissa vilttiin kietoutuneena. Vakuuttaakseen katsojat hän toteaa, että vuokraemäntä on luvannut, että BBC saa olla rakennuksessa kuun loppuun. Näin Monty Python käyttää vastaelokuvallista

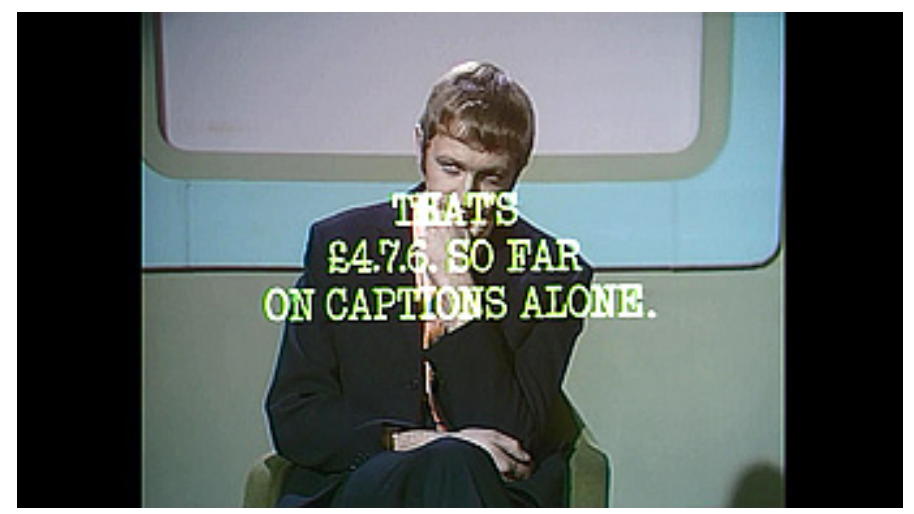

Monty Python käyttää vastaelokuvallista komediaa BBC:n politiikan kritisoimiseen. Kuva: kuvakaappaus DVD:Itä. 
komediaa työnantajansa politiikan kritisoimiseen veronmaksajille tuotetun viihteen avulla. Kyseessä on Monty Pythonille poikkeuksellisen suora tapa käyttää vastaelokuvan tekniikkaa jonkin tietyn päämäärän ajamiseen.

\section{Wollenin vastaelokuvan typologia ja Monty Pythonin komedia}

Vuoden 1982 artikkelissaan Wollen esittelee vastaelokuvan käsitteensä synnit-hyveet-metaforansa mukaisesti. Keskeisin tavoite on, että vastaelokuva paljastaa "hallitsevan" eli valtavirran elokuvan konventiot: katsojaa muistutetaan epäsuorasti siitä, että katsoessaan valtavirran elokuvaa heille esitetään elokuvaa erittäin konstruoituna mutta konstruoinnin mahdollisimman tarkkaan piilottavana kokonaisuutena. Vastaelokuvan perustekniikoita tämän tavoitteen saavuttamiseksi ovat kameran läsnäolon paljastaminen, kerronnan rikkominen ja ylipäätään todellisuusilluusion rikkominen ja illuusion mahdollistavan katsojan samastumisen estäminen. Elokuvatutkija Steve Neale kutsuu todellisuusilluusiota "prosessin näkymättömyydeksi" (invisibility of process) (Neale 1980, 30-31), mikä on siis valtavirran elokuvan kerronnallis-esteettinen päätavoite. Wollenin termistöä käyttäen valtavirran elokuvan "suljettu" (closure) tarinamaailma korvataan vastaelokuvassa "avoimella" tai aukkoja sisältävällä (aperture) kerronnalla. Tätä ideaa tukevat yllä mainittu episodimaisuutta vastaava "kerronnan soljuvuus" (narrative transitivity) vastakohtanaan "kerronnan katkonaisuus" (narrative intransitivity) sekä yksi diegeettinen taso (single diegesis), joka vastaelokuvassa korvautuu useina diegeettisinä tasoina (multiple diegesis) (Wollen 1982, 79-81, 84-87). ${ }^{17}$

Lentävässä sirkuksessa vastaelokuvan tekniikoita käytetään tehokkaasti pitkässä sketsissä "The Golden Age of Ballooning" (40, lokakuu 1974). Sketsi alkaa Gilliamin animaatiolla kuumailmapalloista kamarimusiikin soidessa. Ruudulla on sketsin nimen mukainen otsikko. Kuvatekstiä "The Beginnings" seuraa leikkaus wc-istuinta korjaavaan putkimieheen (Palin), joka työnsä ohessa alkaa kertoa katkonaisesti kuumailmapalloilun historian alkuvaiheista: "Vuonna 1783 Montgolfierin veljekset tekivät ensilentonsa rakentamallaan pallolla..." Seuraa leikkaus, eikä televisiojuontajaa/historioitsijaa tuuraavaa putkimiestä nähdä enää.

Sen sijaan siirrytään 1800-luvun ranskalaiskartanon piirustushuoneeseen, jossa seisovat Montgolfierin veljekset (Idle ja Jones). Periodinmukaisiin asuihin pukeutuneet miehet puhuvat "ranskalaisella" aksentilla siitä, kuinka he ovat kokemassa historiallisen hetken. Huomionarvoista on, että miehet katsovat kameraa, vaikka he näyttäisivät puhuvan toisilleen - myös alun putkimies puhui kameralle, mutta hän toimikin selkeästi tarinaa taustoittavan juontajan toimessa ja toisessa diegeettisessä tilassa. Montgolfierit toteavat päätyvänsä "Montesquieun ja Mozartin väliin" historiassa. Näin katsojan suoran puhuttelun ohella veljesten erikoinen ensyklopedinen kommentti estää katsojaa samastumasta tapahtumiin. Seuraavaksi kerrontatyyli muuttuu, ja veljekset puhuttelevat toisiaan konventionaalisten fiktiohahmojen tapaan. Keskustelun aihe vaihtuu historiallisesta tapahtumasta siihen, kuinka usein tulisi peseytyä (viittaus yleisiin käsityksiin menneiden vuosisatojen ranskalaisaristokraattien huonosta hygieniasta nykykäsityksiin suhteutettuna on ilmeinen).

Kuten edellä on todettu, Wollenin mukaan vastaelokuvan keskeisin taiteellinen päämäärä on pitää katsoja tietoisena siitä, että hän katsoo elokuvaa. Vastaelokuvassa valtavirranelokuvan kielen "läpinäkyvyys" (transparency) korvataan vastaelokuvan "etualalle tuomisena" (foregrounding), eli valtavir-
17 Ainoa todella kriittinen kohta Wollenin vastaelokuvan typologiassa on jako valtavirran elokuvan "fiktion" ja vastaelokuvan "todellisuuden" välillä. Vaikka näyttelijät improvisoisivat vuorosanansa lavastamattomassa miljöössä, argumenttia on käytännössä mahdoton hyväksyä. Esimerkiksi yllä mainitusta vastaelokuva-keskustelusta voidaan nostaa esiin Polanin argumentti, jonka mukaan etäisyys "todellisuudesta" on taiteeseen sisäänrakennettu ominaisuus (Polan 1974). Itse asiassa Wollen täsmentää, että "hallitseva" elokuva - siis valtavirranelokuva - tuottaa "fiktiota", joka on maailman "mystifiointia", ja tämän takana on porvarillinen ideologia. Wollenin "todellisuus"-väitettä voi kuitenkin lähestyä myös siitä näkökulmasta, että naisten/feminististä elokuvaa on määritelty vastaelokuvana. Claire Johnston kirjoitti vuonna 1974, että elokuvan merkitykset ovat aina tuotettuja, mutta tässä on aste-eroja. Niinpä hänen mukaansa kamera tallentaa hallitsevan ideologian "luonnollista" maailmaa, mutta naisten elokuvalla ei ole varaa vastaavaan idealismiin. Naisten alistamisen "totuutta" ei voi "vangita" selluloidille kameran "viattomuudella", vaan alistamisen esittäminen on tietoisesti konstruoitava/lavastettava. (Johnston 2000, 29; Butler, 2007, 93-94.) Johnston itse asiassa hahmottelee artikkelissaan "aidosti vallankumouksellista vastaelokuvaa" todeten, että perinteinen jako elokuvasta poliittisena työkaluna tai viihteenä tulisi purkaa mainitun tavoitteen saavuttamiseksi (Johnston 2000, 28-33). 
ran elokuva pyrkii tekemään elokuvan kielen huomaamattomaksi, kun taas vastaelokuva tekee sen näkyväksi ja eksplikoiduksi. Katsojan samastuminen (identification) halutaan estää vieraannuttamalla (estrangement): empatia ja tunteellinen osallistuminen tehdään vaikeaksi tai mahdottomaksi katsojan suoralla puhuttelulla, henkilöhahmojen moninaisuudella ja kommentaarilla. Kaikki tämä johtaa siihen, että katsomiskokemus ei johda valtavirran elokuvan tarjoamaan mielihyvään (pleasure), vaan katsojaa halutaan provosoida tuntemaan itsensä tyytymättömäksi (un-pleasure) ja ehkä jopa muuttaa tätä ihmisenä. ${ }^{18}$ Monty Pythonilla ei välttämättä ollut yhtä dramaattisia tavoitteita, mutta yhtä kaikki he tekevät komediassaan toistuvasti katsojan tietoiseksi siitä, että nämä katsovat fiktiota - ja he käyttävät siihen samoja periaatteita kuin vastaelokuva Wollenin määrittelemänä. Erityisen selvää tämä on ryhmän historia-aiheisessa komediassa.

"The Golden Age of Ballooning" -sketsin juoni ja kerronta muuttuvat moniäänisemmäksi sen jatkuessa. Ensin veljeksiä tulee tapaamaan 1900-luvun vaatteisiin pukeutunut mies. Kun puhe palautuu kuumailmapalloiluun, näyttämöhenkilökunta astuu kuvaan ja virittää huoneeseen elokuvaprojektorin - veljekset eivät noteeraa tulijoita lainkaan. Kuumailmapalloilun sijaan projektorilla katsotaan animaatioelokuva veljeksistä kylpemässä, mitä seuraa BBC:n mainos The Golden Age of Ballooning -nimisen televisiosarjan oheistuotteista. Kuuluttajan mukaan seuraavaksi nähdään sarjan toinen jakso. Nyt viimeistään selviää, että aiempi Montgolfier-kohtaus oli siis televisio-ohjelma. Toisessa jaksossa veljeksiä tulee tapaamaan Ranskan kuningas Ludvig XIV, joka on, kuten veljekset toteavat, kuollut jo kauan sitten. "Kuningas" jauhaa purkkaa, puhuu skottiaksentilla ja on ilmiselvästi tullut varastamaan kuumailmapallon piirustukset itselleen.

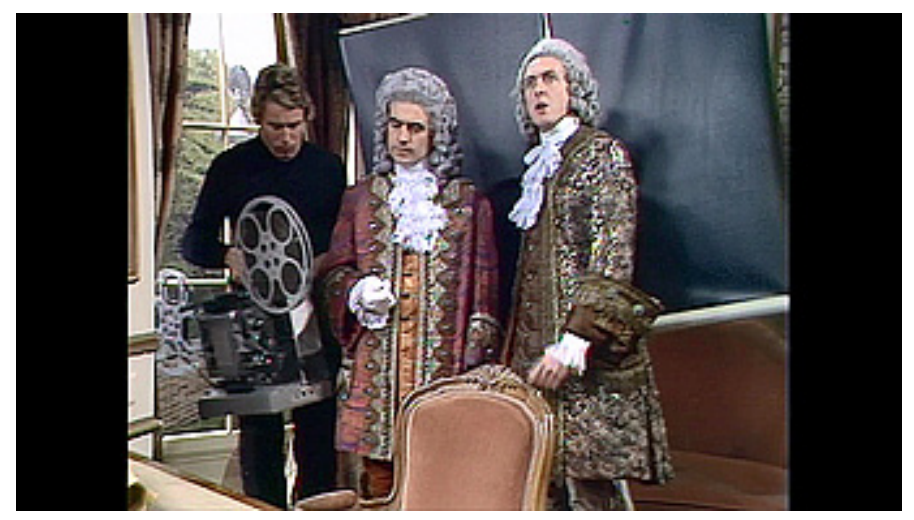

"The Golden Age of Ballooning" -sketsi on "etualalle tuomisen" ja "monidiegeettisyyden" ilotulitusta, jossa elokuvaprojektorilta katsottu filmi näyttelee omaa osaansa. Kuva: kuvakaappaus DVD:Itä.

"Etualalle tuominen" ja "monidiegeettisyys"19 toteutuvat sketsin kaoottisessa finaalissa, kun filmiprojektori tuodaan jälleen lavasteisiin ja ekstradiegeettinen kertojaääni sekä diegeettinen hahmo, veljesten hovimestari, alkavat selostaa ja kommentoida tapahtumien historiallista taustaa ja merkitystä. Molemmat äänet ovat Chapmanin, ja toinen pysyy aiheessa toisen luetellessa todellisia mutta tapahtumille täysin irrelevantteja faktoja. Tekniikoiden vastaavuudesta huolimatta tässä on kuitenkin myös mitä suurimmalla todennäköisyydellä keskeinen ero Wollenin vastaelokuvan ominaisuuksien ja Monty Pythonin komedian välillä: jälkimmäisessä samastumisen estämisen sijaan päämääränä on enemmänkin katsojan hauskuuttaminen. Mikäli näin tapahtuu, katsojalle tuotetaan mielihyvää sen estämisen sijaan. Itse asiassa
18 Wollenin seitsemän ominaisuuden dikotomia on kootusti seuraava: valtavirran/hallitseva/ortodoksinen elokuva - vastaelokuva: 1. narrative transitivity - narrative intransitivity, 2. identification estrangement, 3. transparency-foregrounding, 4. single diegesis - multiple diegesis, 5 . closure - aperture, 6. pleasure - un-pleasure, 7. fiction reality.

19 Genette (1980, 234-237) käyttää termiä metalepsis kuvaamaan kerrontaa, jossa on useampi diegeettinen taso. 
on syytä muistaa, että Wollenin väite, jonka mukaan vastaelokuva estää katsojan mielihyvän, on hypoteettinen ja ehkä virheellinenkin. Pikemminkin voisi ajatella, että vastaelokuvan synnyttämä mielihyvä on erilaista kuin valtavirranelokuvan.

Pythonit ottivat elokuviinsa tarkoituksella mukaan televisiokomediassa käyttämiään ideoita ja perusajatuksia. Niistä keskeisin oli median roolin korostaminen. Niinpä Hullussa maailmassa on runsaasti vastaelokuvallisia tarkoitusperiä ajavia kohtauksia, otoksia ja yksityiskohtia. Pyöreän pöydän ritari Sir Robinin (Idle) mukana kulkeva minstreli (Neil Innes) laulaa isännästään balladin, mutta sen sanat ovat groteskin väkivaltaiset ja paljastavat Sir Robinin pelkuriksi. Balladiparodia sopii musiikilliselta tyyliltään keskiaikaelokuvaan, mutta sen sanoitus on täysin subversiivinen suhteessa lajityyppinsä konventioihin. Kun Arthur ja hänen ritarinsa ovat matkalla Camelotiin, seuraa sanan "Camelot" juhlallista lausumista leikkaus samannimiseen musikaalinumeroon, jossa ritarit tanssivat pöydillä kanojen ja muun irtaimiston lennellessä ympäriinsä. Viittaus amerikkalaiseen musikaalielokuvaan Camelot (Joshua Logan, 1967) on selvä, mutta laulun loppuessa käy ilmi, että ritarit eivät menneetkään Camelotiin juhlimaan. Arthur toteaa, että he eivät menekään Camelotiin, koska se on niin hölmö paikka ("Let's not go to Camelot, it's a silly place").

Lajityypin vaihdoksen ja intertekstuaalisten viittausten (tarunhohtoinen Camelot - musikaaliviihteellinen Camelot) yhdistelmä vastaa Wollenin kerronnallisia "aukkoja" ja monidiegeettisyyttä. Vastaavasti Hullun maailman tarinaa edistetään Disneyn piirretyistä satuelokuvista - kuten kuningas Arthurista kertova A Sword in the Stone (1963) - tutulla tekniikalla eli ekstradiegeettisellä kirjalla, jonka kuvituksen ja kertojaäänen avulla tapahtumia taustoitetaan tai edistetään. Hullussa maailmassa kirja mukailee keskiaikais-
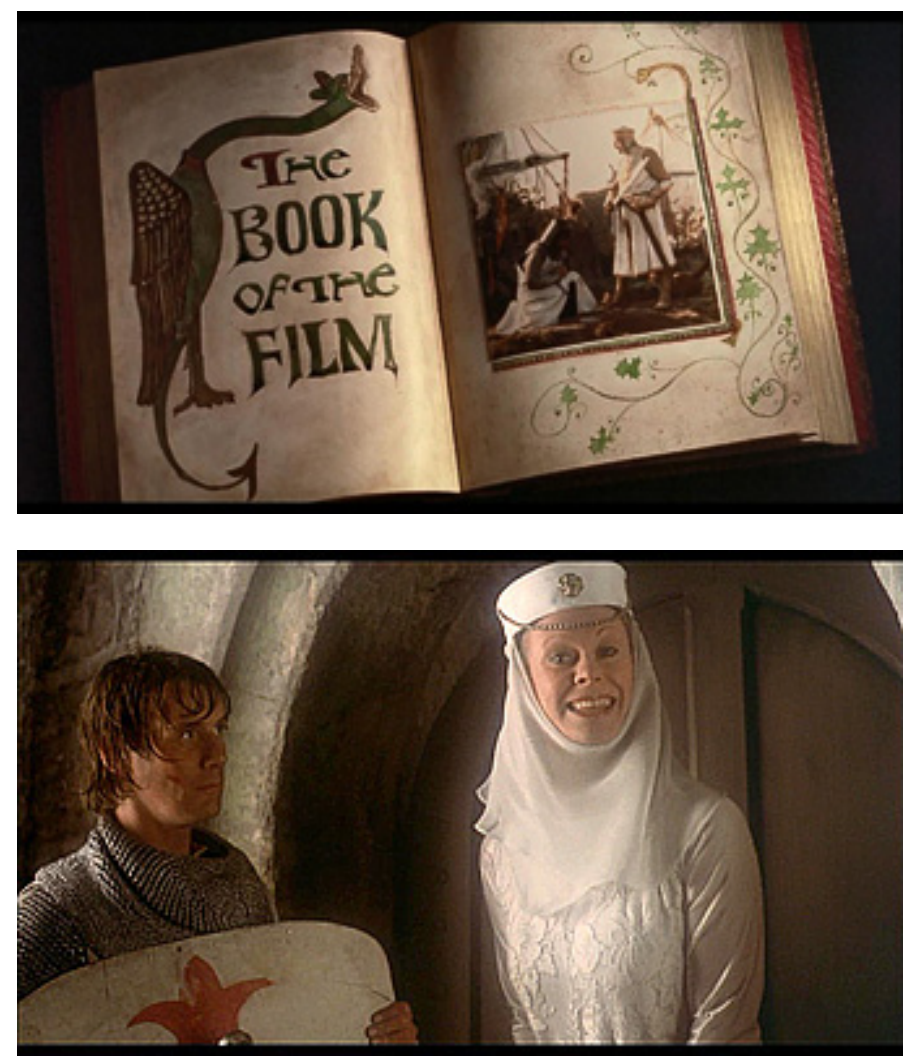

Hullun maailman vastaelokuvallisuuteen liittyy ekstradiegeettinen kirja ja katsojan suora puhuttelu. Kuvat: kuvakaappauksia DVD:Itä. 
ten kirjojen kirjasin- ja kuvitustyyliä, mutta myöhemmin "keskiaikaisessa" kirjassa on still-kuvia elokuvan hahmoista. Tämä on siinä mielessä loogista, että kyseessä on ekstradiegeettisen kertojan mukaan "The Book of Film". Kirja kertoo siis elokuvasta, jonka osa se itse on, ei vaikkapa Arthuriin tai keskiaikaan liittyvästä historiasta.

Epäilemättä suorin vastaelokuvallinen kohtaus elokuvassa on, kun Clevelandin hahmo puhuttelee katsojaa suoraan ja kysyy, että mitä mieltä tämä oli edellisestä kohtauksesta? "Olisiko se pitänyt leikata pois elokuvasta?" "Olimme vähän huolissamme, kun pojat kirjoittivat sen." Eräs elokuvan hahmoista kommentoi toisesta lokaatiosta käsin, että hänestä kohtaus oli huono, käyttäen alatyylistä, keskiaikaelokuvaan "kuulumatonta" kieltä. Näin hahmo tuo etualalle (Wollenin foregrounding) elokuvan muotokielen lisäksi myös diegeettisen kielen konventiot rikkomalla ne.

Monty Pythonin vastaelokuvallisimman kokoillan elokuvan Hullun maailman loppukohtauksessa kuningas Arthurin kokoama soturijoukko lähtee rynnäköimään kohti linnaa, jossa Graalin maljan epäillään olevan. He eivät kuitenkaan pääse tavoitteeseensa, vaan heidät pysäyttää nykyajan (1970-luvun) poliisiosasto. Arthur lähimpine ritareineen lyödään rautoihin ja kuljetetaan poliisimaijan kyydissä kohti tuntematonta - elokuva loppuu yhtäkkisesti tähän. Huomionarvoista kohtauksessa on myös, etteivät "keskiajan" ritarit näytä hämmästyvän poliisiautojen ilmestymistä tai omaa pidättämistään sen kummemmin. He vain noudattavat elokuvan käsikirjoitusta.

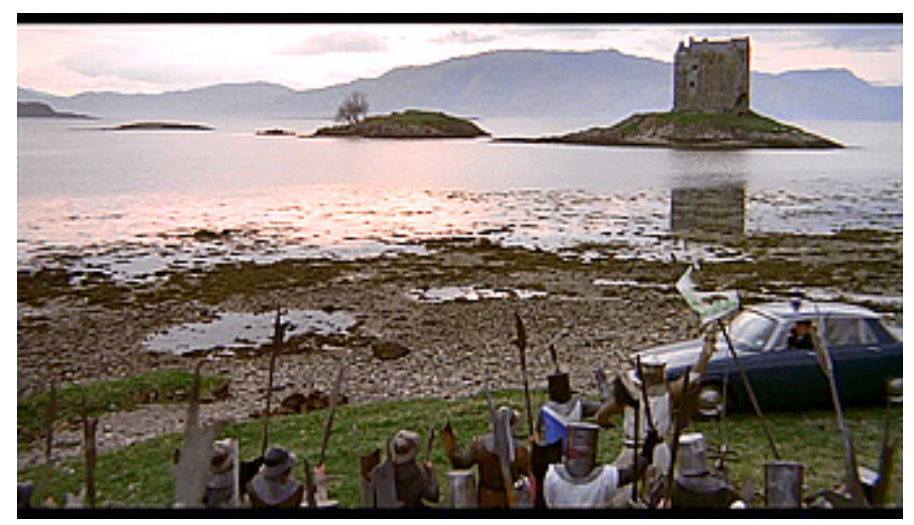

"Keskiajan" ritarit eivät näytä hämmästyvän Hullussa maailmassa poliisiautojen ilmestymistä. Kuva: kuvakaappaus DVD:Itä.

Poliisin ilmestyminen on varmasti katsojallekin yllätys, mutta se on motivoitu kyllä aiemmassa elokuvan kohtauksessa. Kohtaus alkaa klaffilla ("History for Schools, Take 8"). Stereotyyppiseltä brittihistorioitsijalta näyttävä vanhempi keski-ikäinen mies - kuvatekstin mukaan hän on "kuuluisa historioitsija" ("A famous historian"), mutta häntä ei nimetä - alkaa selostaa Arthurin ja ritarien vaiheita edistäen näin elokuvan tarinaa. Hän ei pääse pitkälle, kun oikealla hevosella ratsastava ritari karauttaa paikalle ja iskee miehen maahan miekallaan. Historioitsijan vaimo ryntää paikalle. Tätä rikosta selvittäessään poliisi saapuu paikalle pidättämään Arthurin miehineen juuri ratkaisevan rynnäkön hetkellä. Loppuratkaisu kiteyttää elokuvan vastaelokuvallisen komediallisuuden, mutta se viittaa myös komedian perusluonteeseen, joka muistuttaa myös komediallisen ja ei-komediallisen eroista.

Chapmanilta kysytään BBC:n Film Night -ohjelman reportaasissa Hullun maailman kuvauspaikalla, löytävätkö ritarit etsimänsä Graalin maljan. Chap- 
man paljastaa, että eivät löydä. Haastattelija kysyy, että eikö se ole aikamoinen pettymys katsojalle. Chapman vastaa, että se on kova pettymys ja että itse asiassa koko elokuva on "suuri antikliimaksi". Tämä on mielenkiintoista Geoff Kingin komediasta esittämän havainnon valossa. King nimittäin kirjoittaa, että komediassa (ja huumorissa) inkongruenssi eli epäjohdonmukaisuus, yhteensopimattomuus johtaa tyypillisesti siihen, että sen sijaan, että kehitys olisi kohti suurempaa ja vaikuttavampaa, odotukset yhtäkkiä latistuvat ja häviävät ilmaan: jännittynyt odotus muuttuu ei-miksikään (King 2002, 13-14). Toisin sanoen postmodernistisen komedian draaman kaari, ainakin Monty Pythonin kaltaisessa varsin kyynisessä komediassa, ei nouse huipennukseen vaan loppuu odottamattomasti, luodut odotukset pettäen. Tässäkin mielessä Monty Pythonin komedia on vastaelokuvallista.

\section{Lopuksi}

Monty Pythonin komedian ymmärtäminen vastaelokuvan käsitteen avulla on tärkeää kahdesta syystä. Ensinnäkin ne olivat aikalaisilmiöitä, eli ne auttavat selittämään toisiaan aikakauden eli 1970-luvun kulttuurisessa kontekstissa. Molemmissa ilmiöissä oli kyse valtavirran elokuvan, laajemmin taiteen ja viihteen yhteiskunnallisesta ja kulttuurisesta merkityksestä ja tehtävästä. Toisekseen on ymmärrettävä niiden välinen keskeinen ero. Siinä missä Wollenin mielestä vastaelokuvan tuli, brechtiläisessä mielessä, tehdä yleisö tietoiseksi elokuvan "porvarillisesta" vaikuttamisesta, Monty Python käytti samoja tekniikoita audiovisuaalisten tekniikoiden paljastamiseen ensi sijassa hauskuutustarkoituksessa. Voidaan olettaa, että heidän komediansa vastaelokuvallisuus myös vaikutti katsojien mediatietoisuuteen, mutta tällaista tavoitetta he eivät ole ainakaan julkisesti tuoneet esiin. Yhtenä syynä tähän voi olla heidän edellä mainittu tietoisuutensa komedian alemmasta statuksesta suhteessa draamaan.

Joka tapauksessa Monty Pythonin komedia auttaa ymmärtämään vastaelokuvaa ja ei-komediallisuutta laajemmassa kulttuurisessa mielessä, sillä jo pelkkä parodia on konventioiden avaamista, vastaluennan tuottamista. Molemmissa, vastaelokuvassa ja komediassa, on lopulta kyse "hallitsevien" kerrontatapojen dekonstruktiosta. Monty Pythonin komedia ja vastaelokuva ovat pitkälti rinnakkaisia aikalaisilmiöitä, erona on ennen kaikkea perusmoodi: Monty Python on komediaa, vastaelokuva ei ole. Wollenin teesit ovat sidottuja aikaansa, ja niin on Monty Pythonin komediakin. Tästä huolimatta molempien perusajatukset ovat edelleen relevantteja ja sovellettavia konsepteja pohdittaessa edelleen kulttuurissamme vahvasti vaikuttavan fiktion ja sen todenmukaisuuden luonnetta ja toimintamekanismeja.

\section{Kirjallisuus}

Abercrombie, Nicholas (1996) Television and Society. Cambridge: Polity Press.

BBC Film Night: Monty Python \& the Holy Grail Location Report (1974) - Monty Python and the Holy Grail DVD, 2002.

Billig, Michael (2005) Laughter and Ridicule: Towards a Social Critique of Humour. Lontoo: Sage. Bordwell, David (1979) “The Art Film as a Mode of Film Practice". Film Criticism vol. 4:1, 716-724. 
Briggs, Asa (1979) Governing the BBC. Lontoo: British Broadcasting Company.

Brown, Geoff (1975) "Monty Python and the Holy Grail". Monthly Film Bulletin, huhtikuu 1975, 84-85.

Brown, Geoff (1977) “Jabberwocky”. Monthly Film Bulletin, huhtikuu 1977, 72-73.

Butler, Alison (2007) "Avant-Garde and Counter-Cinema". Teoksessa Pam Cook (toim.) The Cinema Book. Kolmas painos. Lontoo: British Film Institute, 89-95.

Caughie, John \& Rockett, Kevin (1996) The Companion to British and Irish Cinema. Lontoo:

British Film Institute.

Charney, Maurice (1987 [1978]) Comedy High \& Low: An Introduction to the Experience of Comedy. New York: Peter Lang.

Cleese, John (2014) So, Anyway... Lontoo: Arrow Books.

Cook, Pam (2007) "Auteurism, Godard and Counter-Cinema". Teoksessa Pam Cook (toim.) The Cinema Book. Kolmas painos. Lontoo: British Film Institute, 467-468.

Genette, Gérard (1980) Narrative Discourse: An Essay in Method. Käännös ranskasta Jane E. Lewin. Ithaca, New York: Cornell University Press.

Genette, Gérard (1997) Paratexts: Thresholds of Interpretation. Cambridge: Cambridge University Press.

Gow, Gordon (1974) “He Said with Terrible Arrogance...” Films and Filming, joulukuu 1974, $12-17$.

Harries, Dan (2000) Film Parody. Lontoo: British Film Institute.

Hedling, Erik (1997) "Lindsay Anderson and the Development of British Art Cinema". Teoksessa Robert Murphy (toim.) The British Cinema Book. Lontoo: British Film Institute, 178-186.

Hedling, Erik (1998) Lindsay Anderson: Maverick Film-Maker. Lontoo, Washington: Cassell.

Hoffman, Donald L. (2002) "Not Dead Yet: Monty Python and the Holy Grail in the Twenty-First Century". Teoksessa Kevin J. Harty (toim.) Cinema Arthuriana: Twenty Essays. Tarkistettu painos. Jefferson, NC, Lontoo: McFarland, 136-148.

Jeavons, Clyde (1979) “Monty Python's Life of Brian” Monthly Film Bulletin vol. 46:550, 229.

Johnston, Claire (2000) "Women's Cinema as Counter-Cinema". Teoksessa E. Ann Kaplan (toim.) Feminism and Film. Oxford: Oxford University Press, 22-33.

King, Geoff (2002) Film Comedy. Lontoo, New York: Wallflower Press.

Landy, Marcia (2005) Monty Python's Flying Circus. Detroit: Wayne University Press.

Lesage, Julia (1983) “Godard and Gorin's Left Politics, 1967-1972”. Jumpcut nro 28, huhtikuu 1983, 51-58.

Lovell, Alan (1982) “Epic Theatre and the Principles of Counter-Cinema”. Jump Cut nro 27, heinäkuu 1982, 64-68.

Martin, Sean (2013) New Waves in Cinema. Harpenden: Kamera.

Morgan, David (1999) Monty Python Speaks! New York: Avon.

Mähkä, Rami (2016) Something Completely Historical: Monty Python, History and Comedy. Turku.

Neale, Steve (2001) “Monty Python's Flying Circus”. Teoksessa Glen Creeber (toim.) Television Genre Book. Lontoo: British Film Institute, 64.

Neupert, Richard (2007) A History of the French New Wave Cinema. Madison: University of Wisconsin Press.

Palin, Michael (2006) Diaries 1969-1979: The Python Years. Lontoo: Phoenix.

Palmer, Jerry (1987) The Logic of the Absurd: On Film and Television Comedy. Lontoo: British Film Institute.

Polan, Dana B. (1974) "Brecht and the Politics of Self-Reflexive Cinema”. Jump Cut nro 1, 1974.

Rubinstein, Lenny (1985) "Monty Python Strikes Back: An Interview with Michael Palin". Cineaste vol. xiv:2, 6-9.

Stokes, Jane (1999) On Screen Rivals: Cinema and Television in the United States and Britain. Hampshire, Lontoo: Macmillan. 
Stott, Andrew (2005) Comedy. Lontoo, New York: Routledge.

Street, Sarah (1997) British National Cinema. Lontoo, New York: Routledge.

Styan, J. L. (1962) Dark Comedy: The Development of Modern Comic Tragedy. Cambridge: Cambridge University Press.

Thompson, John O. (1982) Monty Python: Complete and Utter Theory of the Grotesque. Lontoo: British Film Institute.

Topping, Richard (2007) Monty Python: From Flying Circus to Spamalot. Lontoo: Virgin.

Walker, Alexander (1985) National Heroes: British Cinema in the Seventies and Eighties. Lontoo: Harrap.

Williams, Raymond (1975) Television: Technology and Cultural Form. New York: Schoken.

Wollen, Peter (1982) Readings and Writings: Semiotic Counter-Strategies. Lontoo: Verso. 